\title{
Amnesty International and Refugee Reforms
}

\author{
by David Matas
}

\section{Introduction}

Amnesty International (AI) is a human rights organization with a limited mandate. It is opposed to torture and the death penalty. It opposes political imprisonment for those who neither use nor advocate violence. It advocates fair trial.

Amnestry International is concerned about refugees who, in their home countries, face the same human rights violations AI combats. Refugees forcibly returned to their countries may be executed. They may be jailed for no other reason than for their opinions. They may be denied a fair trial. Indeed, many refugees already suffered torture, political imprisonment or unfair trail before they fled.

A refugee should not be forcibly returned from Canada to a country where his life or freedom is threatened. That is a Canadian international obligation, by virtue of the Refugee Convention which Canada has signed and ratified. It is also an $\mathrm{AI}$ concern by virtue of its mandate.

The Canadian refugee determination process should be a fair one, with universal access. In the absence of these standards genuine refugees will be returned to countries where their lives or freedom may be threatened.

Amnesty International insists that its members only work against human rights violations abroad. The reasons are three-fold. One is to protect the AI member from danger he may risk, at least in some countries, from opposing his own govemment. The second is impartiality. Opposing a foreign government is less likely to be seen as taking sides in the foreign country's political debates. The third is internationalism. Amnesty International wants its members to widen their concerns beyond their own frontiers.

Refugee work is an exception to this principle. Although AI looks to members in the home country to deal with refugee concerns, the principle of internationalism is respected, since refugee work inevitably relates to foreign human rights violations. By definition, no one is a refugee in his own country. As well, refugee laws and procedures are everywhere complex. An AI member in the home country is best placed to understand and respond to these complexities. Finally, allowing national AI sections to deal with refugee concerns in their countries frees the International Secretariat of
AI to work on torture, the death penalty, political imprisonment, and unfair trial in the countries where these violations take place.

The Government of Canada recently introduced some changes in the present refugee determination system, and proposed an altogether new system. Both the present changes and the new proposal give Amnesty International -- Canadian Section (English Speaking) (AI-CS (ES)) cause for concerm. Our four concerns are: access, appeals, abuse control and deterrence.

\section{Access}

A fair refugee determination procedure is meaningless if the claimant cannot invoke the procedure. At present the Canadian procedure is accessible. Anyone in Canada or at a port of entry can make a refugee claim. The only ones excluded, by statute, are those who have completed their immigration inquiries but want a second access, or those who had access but took no advantage of it and did not go to inquiry. In general, before anyone can be removed from Canada, he has to go to an immigration inquiry. At the inquiry the person can make a refugee claim. Even a person ordered deported by the Minister, without an inquiry, can make a refugee claim.

The proposed Government change is to restrict access for four types of claimants:

- Those recognized as refugees elsewhere.

- Those who delayed making a claim after their entry into Canada.

- Those who have unsuccessfully claimed refugee status in Canada before.

- Those who are under a removal order from Canada.

The last two categories are similar to those denied access now. Those recognized as refugees elsewhere now are granted access to the Canadian refugee determination system, but are not necessarily allowed to stay, even if Canada recognizes them as refugees. A refugee who has made a claim at inquiry is lawfully in Canada only if he is given a Minister's Permit. The Department of Employment and Immigration does not give Minister's Permits to refugees as a matter of course. If a refugee has been recognized as a refugee elsewhere and has a right to return to the country previously granting him refugee status, the policy of the Department is not to grant the person a Minister's Permit.
The real concern about access relates to the second restriction, those who have delayed making a claim after entry into Canada. There are all sorts of reasons why a genuine refugee might delay making a claim. He may hope the situation in his home country will improve, only to realize, after some time has passed, that it is deteriorating. A delayed claim is not necessarily an abusive claim.

The Government proposal indirectly recognizes this point by providing immigration officials the discretion to grant claimants access. This discretion is reviewable by the Federal Court.

However, immigration official discretion with a review by the Court is no substitute for direct access. For one thing, this provision violates the principle of independence. Refugee determination must be independent from immigration admission determination. In the absence of a determination by an independent body, refugee claimants might be denied access because immigration officials feel the claimants are being given an opportunity to remain in Canada, to which they would not have been entitled if they had to meet normal immigration criteria. Immigration officials might deny access to the refugee determination system in order to maintain the integrity of the immigration system.

The present refugee determination system recognizes this principle of independence. The members of the Refugee Status Advisory Committee (RSAC) who advise the Minister of Employment and Immigration on refugee decisions, are supposed to be independent from the Department of Immigration. However, the principle is abandoned when it comes to access.

There is also the problem of competence. An immigration official who denies access is, in effect, making a refugee determination. To do so, he must be familiar with conditions in the country the refugee has fled and with refugee law. It is unlikely that immigration officials will have the expertise to function effectively in making access decisions.

Similarly, review by the Federal Court is no answer to incompetence of the original deciding authority. The Federal Court is an appropriate body to review an expert administrative tribunal. It cannot compensate, with an expertise it does not have, for incompetence of the original decision-maker. 
In 1985, the Supreme Court held that, by virtue of the Canadian Charter of Rights and Freedoms, refugee claimants are entitled to oral hearings, even though the Immigration Act said that they were not. In my opinion, a refugee claimant denied access is denied the oral hearing to which the Supreme Court of Canada says he is entitled. There is every reason to believe that a limitation of access is unconstitutional.

Unconstitutional or not, denial of access is unfair to refugees. Amnesty International believes that access should be universal.

\section{Appeals}

Currently, the Minister of Employment and Immigration, who determines refugee status, appeals to the Immigration Appeal Board (IAB). The IAB appeal is a process of redetermination which, since the 1985 Supreme Court decision, requires an oral hearing. After the Supreme Court decision, Parliament amended the Immigration Act to allow for an oral hearing in every case. From the IAB, a claimant can go to the Federal Court of Appeal, on a motion to set aside the IAB decision. The available grounds before the Federal Court Appeal are excess of jurisdiction, error in law, failure of natural justice, and arbitrary finding of fact. The claimant can go to the Supreme Court of Canada from the Federal Court of Appeal on a motion for leave to appeal.

The Govemment proposal would remove the Minister, the RSAC and the IAB from this process. A newly constituted Refugee Board would determine refugee claims by way of oral hearing. Instead of being able to go to the Federal Court of Appeal on a motion to set aside, the claimant could go to the Court only by way of leave to appeal. The grounds for leave would be limited to those that exist now on a motion to set aside a decision of the IAB: excess of jurisdiction, error in law, failure of natural justice, and perverse finding of fact.

One problem with this proposed appeal system is that access to the Supreme Court of Canada is cut off. Though the proposal does not explicitly prevent access, that would be the end result of its implementation.

In a 1979 refugee case, the Supreme Court of Canada held that it has no jurisdiction to grant leave to appeal for those who had been denied in the court below. This case ruled on an old law in effect before April 10, 1978, which stated that cases went to the Federal Court of Appeal only by way of leave. In the 1979 case, the Supreme Court of Canada held it could not look at the issue, because the Federal
Court of Appeal had refused leave to appeal. This decision placed in question the faimess of the refugee determination process. The Government now proposes to make the old law relevant again. If the proposed system had always been in place, the Supreme Court decision granting oral hearings to all claimants, held under the present appeals system, could never have been made.

Under the proposed system the Federal Court of Appeal would not deny leave in every case. For those cases granted leave, the claimant would have access to the Supreme Court of Canada, should he lose at the Federal Court of Appeal. The problem arises where a claimant loses on an issue at the Federal Court of Appeal, after the granting of leave, and chooses, for whatever reason, not to go to the Supreme Court of Canada. Once leave is denied, access to the Supreme Court is foreclosed.

A second problem with the proposed system of appeal to the Federal Court of Appeal is that a leave to appeal is not the same as an actual appeal. A person denied leave has been denied an appeal.

Even a person granted leave does not have a true appeal, because there is no appeal on error of fact. The Refugee Board could be wrong in fact, but, as long as its error was nor arbitrary or perverse or capricious, the Federal Court of Appeal would have no power to correct the error.

This system is a violation of international standards. One of the guarantees for refugee determination procedures recommended by the Executive Committe of the United Nations High Commission for Refugees (UNHCR), is an appeal that involves a formal reconsideration of the refugee decision. The Canadian proposal violates the recommended guarantees, by not providing formal reconsideration of the factual issues.

The recommended guarantees are not part of the Refugee Convention. They are, however, designed to safeguard against violations of the Convention. Where there is no apppeal, the likelihood of violation of the Convention, by forcible return of a refugee to a country where his life or freedom would be threatened, is greater.

The proposed refugee appeals system is also a violation of Canadian standards of justice. An erroneous refugee determination may result in death to the claimant denied. In contrast, a Canadian criminal suspect faces far less dire consequences and is given a good deal more protection. The accused is given two trials of fact, the preliminary inquiry, and the trial itself.

In addition, courts of appeal in criminal cases can overturn a conviction, where an error of fact is made. The error of fact does not have to be perverse or capricious. It is enough if the verdict is unreasonable, or cannot be supported by the evidence.

Amnesty International has proposed a centralized paper review of negative decisions based on the merits of the claim. The appeal authority would have the power to reverse or confirm or refer the claim for another hearing before a different panel of the proposed Refugee Board. This model is only one of several possible models. What is important is not that this particular model be adopted, but that the principle of appeal is accepted.

\section{Abuse Controls}

A properly functioning refugee determination procedure must control abuse. Abuse can be controlled through speed and the imposition of visa requirements.

A prompt refugee determination not only curbs abuse by non-genuine claimants, but also benefits the genuine refugee who is in limbo while his claim is being processed. One advantage of the Government proposed reforms is that, by removing several unnecessary steps, they would reduce delays, prevent backlogs and eliminate incentives to abuse.

A determination process can, however, be so speedy it ceases to be fair. That is basically what has happened with the proposed removal of the right of appeal. As in the case of limitation of access, the motive, no doubt, was to prevent delays building up in the system in order to lessen the incentive for abuse. However, speed is gained only at the expense of faimess. It is a sacrifice that should not be made.

Imposition of a visa requirement is another technique for curbing abuse. It is appropriate as a measure to control refugee claimant abuse from source countries which are not gross and flagrant violators of human rights. Imposing a visa requirement is not appropriate in every circumstance. Where refugee claimant abuse is insignificant, where the source country is a gross and flagrant violator of human rights, and where the number of refugees coming to Canada is manageable, such a requirement is not only unnecessary, it further jeopardizes the refugee's welfare. 
In such instances, those wanting to flee persecution cannot leave. They will not be given visitor visas, since they have no intention of returning home. They will not be given immigrant visas unless they meet immigration criteria.

These principles, again, put AI--CS (ES) in conflict with announced Government policy. We believe that the Government has unnecessarily and unfairly imposed visa requirements on countries that have not generated significant refugee claimant abuse, and are gross and flagrant violators of human rights, like Guatemala. We believe the Government should have imposed a visa requirement on Portugal, a country that was generating significant refugee claimant abuse, and is not a human rights violator, much sooner than it did.

The refugee claimant abuse from Portugal has been blamed on unscrupulous immigration consultants and lawyers advising Portuguese to make false refugee claims. Amnesty International believes, however, that the Government must share the blame since it remained inactive long after the fraud appeared. This inactivity did not, in itself, condone the fraud. But it did provide the fraud opportunity and scope.

\section{Deterrence}

The last concern of AI I want to mention is deterrence. There is a direct link between the failure of the Government to respect the principle of non-deterrence, and the failure of the Government to impose a visa requirement on Portugal.

The point of principle here is that refugee claimants who are fleeing persecution should not be deterred from making refugee claims. The Government should not have a policy of making lives so miserable in Canada for refugee claimantas that they are discouraged from making their claims.

At the same time as the government imposed the visa requirement for Portugal, it also made work permits for refugee claimants more difficult to get. Refugee claimants are not entitled to work permits, but they are eligible for them. Until the changes announced on July 16th, their eligibility commenced at the time of the inquiry, when they made their claims. After that date claimants became eligible for work permits only after their examinations under oath, usually some months after the inquiry.
The delay in eligibility for work permits can mean destitution for claimants. Refugee claimants are eligible for welfare in some parts of Canada, but not everywhere. A claimant eligible neither for welfare nor for a work permit may not have any means of support. Because of that he can be discouraged from making a claim or may be tempted to withdraw his claim. Abusive claims may be discouraged by this but, unfortunately, so may be genuine ones as well. Genuine refugee claimants now suffer because the Government was not quick enough in controlling abuse.

\section{Conclusion}

How has the Government come to do what it has done? The reforms recently announced and proposed are the culmination of a long drawnout reform process. In November 1981 a Task Force on Immigration Practices and Procedures recommended a number of changes in refugee procedures in a report titled "The Refugee Status Determination Process". Some of these recommendations were implemented shortly after the release of the report.

The government did not, however, act on the Task Force's recommendation for oral hearings. The Task Force Report was followed by Ed Ratushny's report of May 1984, titled "A New Refugee Status Determination Process for Canada", which also focused on the need for oral hearings. Gunther Plaut's report of April 1985, titled "Refugee Determination in Canada", examined the different ways an oral hearing system could be implemented.

Two weeks before this third report was presented to the Govemment, the Supreme Court of Canada ruled that oral hearings are constitutionally required and that they should be granted by the IAB. In response to the Court's ruling, the Department of Employment and Immigration set about developing its own reform process. As a result, what began as a process of making the system fair for genuine refugee claimants through oral hearings, ended up as a process of abuse control directed against non-genuine refugee claimants. The focus shifted from the genuine claimant and the problems he faced to the non-genuine claimant and the problems he caused.

The principle of independence accepted for refugee decisions, was ignored when formulating refugee policy, because the reforms the Government proposed were developed by the Immigration Department, with Immigration personnel, for immigration reasons. The emphasis was abuse of the non-genuine claimant, rather than the needs of the genuine claimant, because abuse is the main Immigration concern.

So we now have proposed limited access. We have proposed limited appeals. We have limited accessibility to work permits.

Canada has had a humanitarian tradition in its acceptance of refugees. The Government, by its recent steps and proposed policies, has departed from that tradition. Amnesty International urges the Government to return to basic principles for protecting refugees by allowing universal access, by allowing appeals, by using visas to control abuse, but not preventing genuine refugees from arriving, and by not deterring refugee claimants who are here.

David Matas is co-ordinator of the legal network of AI-CS (ES). He was the author of the Task Force Report "The Refugee Status Determination Process". The present article is an edited version of his remarks delivered to the Canadian Human Rights Foundation Summer Course on Human Rights at Charlottetown, PEI, July 22, 1986.

\section{Publications}

The following publications are still available from the Refugee Documentation Project:

- The Indochinese Refugee Movement: The Canadian Experience, edited by Howard Adelman (Toronto: Operation Lifeline, 1980), \$5.00.

- Guide to Sponsorship of Refugees in Canada (Toronto: Refugee Documentation Project-Operation Lifeline, 1981), \$17.00.

- Homeless Refugees and Displaced Persons in Southern Lebanon (Toronto: Refugee Documentation Project, 1982), \$17.00.

- Unaccompanied Children in Emergencies: The Canadian Experience (Toronto: Refugee Documentation Project, 1984, reprinted 1985), \$27.50.

- Report: UNRWA Archives (Toronto: Refugee Documentation Project, 1985), $\$ 17.00$.

- Back editions of Refuge: Single $\$ 1.50$, double $\$ 2.75$.

All prices are exclusive of postage. 